\title{
"Hitting two targets with one shot" in the context of Immigrant entrepreneurship: Case studies in Germany related with entrepreneurial migrant activities for the development of the home and host countries
}

\author{
Ben Collins Vershiyi Kwaven*, Claudia Nelly Berrones-Flemmig**, \\ Utz Dornberger ${ }^{* * *}$
}

This paper aims to contribute to the debate and knowledge of immigrant entrepreneurship in Germany by analyzing a central research question (derived mainly from Dana (2007), Tung (2008), de Haas (2010), Riddle et al. (2010; 2011) Jones et al. (2011), Elo (2014) and Sørensen (2014): How do migrant entrepreneurs in Germany contribute for the economic development of their home and host countries, particularly through aspects related with promotion of international trade and market knowledge?

The relation between migration and the development link in their homelands have been examined in the social sciences (Sørensen, 2014; Riddle et al., 2010) as well as in the field of economics where several authors have analyzed the relations between diasporas and international trade (Gould, 1994; Mundra, 2005; Cohen, 1997).

Germany has long been confronted with growing diversity and interculturalism in its population development. The present debate about the economies of migrants in Germany and Europe is intensifying, particularly due to the increasing interdependence of international markets and the growing networking of economic and trade relations (Dornberger et al., 2009).

In order to answer the central research question of this paper, there have been selected two case studies based on qualitative methods. The results shows that the positive use of the entrepreneur's potentials and networks for the international linkage creation between different countries.

Keywords: Immigrant Entrepreneurship, development, Germany, international entrepreneurship, SMEs.

Submitted: 06.05.17 | Accepted: 26.03.18

\footnotetext{
Ben Collins Vershiyi Kwaven - International SEPT Program Leipzig University.

Correspondence address: Leipzig University, International SEPT Program, Ritterstr. 9-13, 04109 Leipzig, Germany, e-mail: bccool@hotmail.com.

** Claudia Nelly Berrones-Flemmig - International SEPT Program Leipzig University. Correspondence address: Leipzig University, International SEPT Program, Ritterstr. 9-13, 04109 Leipzig, Germany, e-mail: cberrones-flemmig@uni-leipzig.de.

*** Utz Dornberger - International SEPT Program Leipzig University.

Correspondence address: Leipzig University, International SEPT Program, Ritterstr. 9-13, 04109 Leipzig, Germany, e-mail: dornberg@uni-leipzig.de.
} 


\title{
„Dwie pieczenie na jednym ogniu” \\ w kontekście przedsiębiorczości imigrantów: studia przypadku w Niemczech związane $\mathrm{z}$ działaniami przedsiębiorczymi imigrantów na rzecz rozwoju kraju pochodzenia i kraju przyjmującego
}

\begin{abstract}
Niniejszy artykut ma na celu wniesienie wktadu $w$ debate oraz poszerzenie wiedzy na temat przedsiębiorczości imigrantów w Niemczech poprzez analizę podstawowego pytania badawczego [którego źródtem sa gtównie Dana (2007), Tung (2008), de Haas (2010), Riddle i in. (2010, 2011), Jones i in. (2011), Elo (2014), N. N. Sørensen (2014), B. Sørensen (2014)]: $W$ jaki sposób przedsiębiorcy wywodzacy się ze środowiska migrantów $w$ Niemczech przyczyniaja się do rozwoju gospodarczego swojego kraju pochodzenia i kraju przyjmujacego, w szczególności $w$ kontekście promocji handlu międzynarodowego i propagowania wiedzy o rynku?

Zwiazek pomiędzy migracja a rozwojem w ojczyznach imigrantów zostat zbadany w naukach społecznych (B. Sørensen, 2014, Riddle i in., 2010) oraz w ekonomii, gdzie kilku autorów przeanalizowato relacje między diasporami a handlem międzynarodowym (Gould, 1994; Mundra, 2005; Cohen, 2008).

Niemcy od dawna stoja przed problemami wynikajacymi z rosnącej różnorodności i międzykulturowości w rozwoju swojej populacji. Obecna debata na temat migrantów $w$ Niemczech i Europie nasila się, szczególnie ze względu na pogłębiająca się wspótzależność rynków międzynarodowych i coraz ściślejsze powiazania gospodarcze $i$ handlowe (Dornberger i in., 2009). Aby odpowiedzieć na podstawowe pytanie badawcze postawione w tym artykule, wybrano dwa studia przypadku oparte na analizie jakościowej. Wyniki pokazuja pozytywne wykorzystanie potencjatu $i$ sieci przedsiębiorcy $w$ budowaniu międzynarodowych relacji między różnymi krajami.
\end{abstract}

Słowa kluczowe: przedsiębiorczość imigrantów, rozwój, Niemcy, przedsiębiorczość międzynarodowa, MSP.

Nadesłany: 06.05.17 | Zaakceptowany do druku: 26.03.18

JEL: L26, M16, O15

\section{Introduction}

\subsection{Background and scientific definition of the problem}

In 2000 the world leaders committed their countries at the United Nations Headquarters to adopt the Millennium Development Goals (MDGs) in order to reduce extreme poverty and setting particular targets (with a deadline of 2015). The eight MDGs setted by 2015 did not include goals and targets related to migration. Some argue that this is because the migration-development nexus was not yet established in the international policy agenda Since 2003 there is an increasing attention to the migration development link. This attention increased particularly when the Global Development Finance Annual Report registrated formally the remittances to developing countries (Sørensen, 2014). Furthermore, the aspect of how the grow- ing immigrant contributions could promote development in their home countries has increased the attention among scholars and in both public and private forums. Nevertheless, the discussion about diaspora contributions for development is mostly reduced to the impact of remittances. But, the influence of migration extends beyong remittances: immigrant entrepreneurship has been developed in the recent years with successful entrepreneurs extending their business to their home developing countries, with relevant impacts on capital, technology and market knowledge (Sharma et al., 2011).

Germany has long been confronted with growing diversity and interculturalism in its population development. According to a recent study from the Mannheim Institute for SME Research (Leicht and Berwing, 2016), founders with a migration background in Germany have created 
2.5 million jobs. The present debate about the economies of migrants in Germany and Europe is intensifying, particularly because of the increasing interdependence of international markets and the growing networking of economic and trade relations. Therefore, it is important to make a positive use of these potentials for the internationalization process. The promotion of these potentials is an important building block for the competitiveness in Germany and at the same time supports the economic development in other countries with an economic relation with Germany (Dornberger et al., 2009). The importance of migrant entrepreneurs with international businesses in Germany is particularly relevant and there is a gap in the scientific literature in this area. According with King and Collyer (2016), the fields of migration and development studies remained separated until recently. This means that migration scholars said little regarding development and development experts discussed little about migration. In the post-war period until the early 1990s, the leading European discourse concentrated on labour-market needs, defining it as "guest worker" immigration. It is important to highlight that this discussion almost not took into consideration the recognition of migrants as relevant links to their home countries and their impact for development there. The literature review from Elo (2014) shows clearly that the following central aspects require further research: diaspora networks in knowledge transfer, innovation and opportunity development; diaspora networks for conducting international business; diaspora networks as catalysts in international entrepreneurship; forms and definitions of migrant businesses and their international entrepreneurial activities. Furthermore, the aspects of migration and diaspora have been developed more in other disciplines different from international business (Jones et al., 2011). Moreover, there is gap in theory-building and qualitative studies in the field of immigrant entrepreneurship (Aliaga-Isla and Rialp, 2013). It is clear that the identification of categories in European migrant entrepreneurship is not easy and requires further comparative case studies at national, international and European level (Baycan-Levent and Nijkamp, 2009). Therefore, it is important to develop explorative case studies related with immigration entrepreneurship in Germany, in order to identify patterns in the area and later to conduct empirical quantitative studies in the field.

\subsection{Main research question}

This paper aims to contribute to the debate and knowledge of migrant entrepreneurs in Germany by analyzing a central research): How do migrant entrepreneurs in Germany contribute for the economic development of their home and host countries, particularly through aspects related with promotion of international trade and market knowledge?

In order to answer this question, there have been selected two particular case studies, which are based on a qualitative analysis of Cameroonian migrant entrepreneurs in Germany (Vershiyi, 2014).

\section{Theoretical Background}

\subsection{Relevant definitions: clarifying terminology}

In the areas of immigrant, diasporas and international entrepreneurship, there is a multifaceted terminology. It is relevant to define the main central definitions in the present paper, according with the contribution from Elo (2014): Immigrant entrepreneurship is a "socio-economic phenomenon with implications for regional and economic development" (Aliaga-Isla i Rialp, 2013). This type of entrepreneurship often it is defined with a first-generation focal point. Diasporans are "migrants who settle in some places, move on, and regroup; they may also be dispersed; and they are in a continuous state of formation and reformation" (Cohen, 2008, p. 142). Diasporans as international entrepreneurs have been identified as factors in economic activity and development in developing countries (Nkongolo-Bakenda and Chrysostome, 2013), the effect is not reduced to one country setting. Diaspora networks are a tool that plays a relevant role reducing the costs of brain drain by promoting cooperation and contributing with knowledge and skills, as well as with collective and business investment (Dayton-Johnson et al., 2009). International entrepreneurship is ,a combination of innovative, proactive and risk-seeking behaviors that crosses national borders and is intended to create 
value in organizations" (McDougall and Oviatt, 2000, p. 903).

According with the definitions before, the present paper is focused mainly on exploring immigrant entrepreneurship from diasporans with diaspora networks, particularly for the purpose of conducting business crossing national borders (international entrepreneurship).

\subsection{Relevant perspectives, theories and concepts}

In the four decades, there has been an academic debate surrounding migration and development. According to de Haas (2010), the debate on migration and development is similar to a pendulum, from a developmentalist optimism in the $1950 \mathrm{~s}$ and 1960s, to a neo-Marxist pesimmism over the 1970s and 1980s and then more optimistic views in the 1990s and 2000s. These perspectives are particular relevant in social and development theory (de Haas, 2010 and Sørensen, 2014).

The Optimists: developmentalist and neoclassical views

In the 1950s and 1960s began the developmentalist era, where it was assumed that poor countries can be able to achieve modernization through large-scale capital transfer and industrialization. This approach assumes that the newly decolonialized countries in this period achieve economic growth and follow the same path of modernization and industrialization, similar as many of the Western countries before (Sørensen, 2014). This period was dominated by large-scale migration from developing to developed countries and migration was perceived as an ideal allocation of production factors with a benefit in both the sending and the receiving countries. In other words, migrants were perceived in this period as important agents of change, investors and innovators. Therefore, this perspective believed that remittances, experience, skills and knowledge acquired from the migrants abroad would support developing countries in achieving economic development. This neoclassical perspective of migration and development was the dominant view in most of the international financial institutions worldwide until recently. For example, the World Bank recognized the benefits of the migrant receiv- ing countries but it did not consider the remittances (de Haas, 2010, de Haas, 2007; Sørensen, 2014).

The Pesimists: Historical structural and dependency views

Since the optimistic perspectives faced several challenges increasingly, the 1970s and 1980s were dominated by a neoMarxist thinking, with a shift in social and development theory towards dependency perspectives. The change in the paradigm regarding migration and development had been started by the 1973 oil crisis, which represents a period of worldwide economic downturn, increase in unemployment and industrial restructuring. Migration was perceived at this time as an important cause of underdevelopment and damage to the underdeveloped countries. This perception of migration believes that the migrant-sending economies deprive them of material and human capital, increasing the dependence on the developed countries and contributing to unequal growth (de Haas, 2010, de Haas, 2007; Sørensen, 2014).

Pluralist Perspectives: new economics of labour migration and livelihood approaches

In the 1990s and 2000s emerged again a more positive attitude about the link between migration and development, as well as migration and remittances. This represented a paradigm shift in social theory, placing the household more than the individual as a decision-making unit. This approach considers the behaviour of households as risksharing and therefore, able to diversify labour with the objective to minimize income risks. This pluralist perspective is known as the „new economics of labour migration" (de Haas, 2007 and Sørensen, 2014).

This paper shares the opinion of the optimistic perspectives (developmentalist and neoclassical views) as well as with the pluralist perspectives presented before. The definition of development is not only reduced to economic growth (like remittances), but also considers other relevant aspects, such as skills and knowledge transfer, increases in capital and market knowledge (Newland and Plaza, 2013; Sharma et al., 2011). 
2.3. Assessment of the impacts

of immigrant entrepreneurs

in their home and host countries

There are different approaches to assess the impact of fhe immigrant entrepreneurs in their home and host countries. On the one hand, in order to evaluate the impact in the home countries, several authors propose relevant aspects such as promotion of trade and Foreign Direct Investment (FDI), skills and knowledge transfer (Newland and Plaza, 2013; Sørensen, 2014). Other authors evaluate the impact in home countries through reduction of poverty, increases in capital, technology and market knowledge (Sharma et al., 2011). On the other hand, for the assessment of the impact in the host countries, some authors point out the reduction of transaction costs of integration (Dornberger et al., 2009) and other authors indicate aspects related with skills knowledge transfers (Newland and Plaza, 2013), reduction of poverty, increases in capital and market knowledge (Sharma et al., 2011).

Table 1. Summary of the Theoretical Framework

\begin{tabular}{|l|l|l|}
\hline & \multicolumn{1}{|l|}{$\begin{array}{l}\text { Assessment of impacts in home } \\
\text { countries (Newland and Plaza, 2013; } \\
\text { Sørensen, 2014; Sharma et al., 2011) }\end{array}$} & $\begin{array}{l}\text { Promotion of trade, FDI, skills, } \\
\text { knowledge transfers and remittances } \\
\text { (Newland and Plaza, 2013; } \\
\text { Sørensen, 2014) }\end{array}$ \\
\cline { 2 - 3 } $\begin{array}{l}\text { Impacts } \\
\text { of immigrant } \\
\text { entrepreneurship } \\
\text { for development }\end{array}$ & $\begin{array}{l}\text { Reduction of poverty, increases } \\
\text { in capital, technology and market } \\
\text { knowledge (Sharma et al., 2011) }\end{array}$ \\
\cline { 2 - 3 } & $\begin{array}{l}\text { Assessment of impacts in host } \\
\text { countries (Dornberger et al., 2009, } \\
\text { Newland and Plaza, 2013; } \\
\text { Sharma et al., 2011) }\end{array}$ & $\begin{array}{l}\text { Reduction of transaction costs } \\
\text { of integration } \\
\text { (Dornberger et al., 2009) }\end{array}$ \\
\cline { 3 - 3 } & $\begin{array}{l}\text { Skills knowledge transfers } \\
\text { (Newland and Plaza, 2013) }\end{array}$ \\
\cline { 2 - 3 } & $\begin{array}{l}\text { Reduction of poverty, increases } \\
\text { in capital and market knowledge } \\
\text { (Sharma et al., 2011) }\end{array}$ \\
\hline
\end{tabular}

Source: own elaboration based on the authors cited.

The different approaches regarding the impacts of immigrant entrepreneurship for development are described and explained in the next part, according with the definitions of the authors mentioned above.

\section{Assessment of impacts in home coun-} $\underline{\text { tries }}$

1. Promotion of trade and FDI (Foreign Direct Investment):

Several research studies have demonstrated the links between diasporas and increase in trade. This is because diaspora members usually create connections between producers and consumers in both host and home countries. At the same time, diaspora members tend to invest in their countries of origin and they persuade also other investors to do the same (Newland and Plaza, 2013 and Sørensen, 2014). These connections promote the internationalization of products and services in the countries involved in form of exports and/or foreign direct investment as well.

2. Skills and knowledge transfers:

Diasporas have often the opportunity to learn valuable skills, experiences and contacts abroad that they can be able to transfer later to their home countries through different ways, like startup businesses, training and mentoring and promoting emerging industries (Newland and Plaza, 2013).

3. Remittances:

Remittances are only one part of the economic development. Economic 
development goes beyond sending remittances (Newland and Plaza, 2013). Nevertheless, migration and remittances represent one relevant co-insurance livelihood strategy by households and families. This is part of the aspects in migration for improving well-being, stimulate economic growth and to reduce poverty in different ways (de Haas, 2007).

\section{Assessment of impacts in host countries}

1. Reduction of transaction costs of integration:

There are different reasons why the entrepreneurial activity of immigrants is so relevant for themselves and for the host country: firstly, since the integration of the "stranger" can proceed more quickly based on trust and recognition. Successful foreign entrepreneurs gain recognition also among the autochthonous population and their success causes an integrative effect. Secondly, successful self-employed migrants and entrepreneurs reduce the societal transaction costs for integration. Thirdly, the integration of the population with a migration background into the socioeconomic networks makes it possible to make full use of the innovative capacity and the potential of governmental growth. Within this aspect, it is important to remind about a relevant issue mentioned before: since there is an increasing interdependence of international markets and the growing networking of economic and trade relations, it is important to make a positive use of the potentials of the internationalization process. The promotion of these potentials is an important building block for the competitiveness in Germany and at the same time supports the economic development in other countries within an economic relation with Germany (Dornberger et al., 2009).

2. Skills and knowledge transfers:

Diasporas have often the opportunity to learn valuable skills, experiences and contacts abroad that they can be able to transfer later to their home countries through different ways, like startup businesses, training and mentoring and promoting emerging industries (Newland and Plaza, 2013).

3. Reduction of poverty:
Relevant experiences about diaspora contributions for development are increasing in the global landscape and it is an oportune moment to reflect about how to use these experiences to promote development and reduce poverty. In this context, several United Nations Programmes and Departments initiated in 2007 a collaboration on a programme with the objectives to identify and analyze policies that will enable developing countries to find and recognize the potential of their diasporas to reduce poverty with the focus of promoting entrepreneurship and private sector development (Sharma et al., 2011).

3 . Increases in capital and market knowledge:

This aspect is relevant because diaspora communities can be able to implement development projects mostly directly related with their country of origin. These projects usually involved financial, human and social capital and include investing in home countries by start up business, investment in fixed assets, capital stock for companies, as well as transfer of skills and knowledge. These contributions are relevant to promote entrepreneurship in their countries of origin (Sharma et al., 2011).

\section{Research Methodology}

The methodology of this paper is mainly exploratory and analyzes two qualitative case studies. For both case studies, Vershiyi (2014) used the methodology of semi-structured telephone interviews with migrant entrepreneurs in Germany.

\section{Location and sample of the research}

The location of both cases analyzed was the city of Berlin, because it represents an ideal city with a mixture of Cameroonian from all regions with several occupations, as well as different association groups. According to official figures, Berlin is one of the cities with highest concentration of Camerooians. Furthermore, it is important to clarify that the Cameroonian diaspora in general is particularly a well-educated and organized community.

Besides, Cameroonian migrants constitute a greater part of the German's African population. Recent official statistics 
of the city of Berlin (as December, 2016) show that in 2016 officially lived 2262 Cameroonians in Berlin (Annual report, official statistics from the city of Berlin, 2017).

\section{Sample methods and criteria of selec-} $\underline{\text { tion }}$

The sampling that has been used for this study is acquired through networking contacts of the researcher and the use of purposive and snowballing techniques (Robson, 2002). Purposive sampling allows the researcher to use his judgment in choosing respondents with the suitable experience and expertise that would best enable him to answer the research questions and thus meet the study objectives. On the other hand, snowball sampling is a chain referral method used to identify potential participants based on the recommendations of others (Altinay and Wang, 2009).

The main criteria of selection of the entrepreneurs was: small Cameroonians entrepreneurs in Berlin, which are owners and managers of an established formal company in Germany, related in some way with international trade between Cameroon and Germany.

\section{Interview design}

The interviews conducted were semistructured and by telephone (with a duration of 45 minutes each one), with an interview guide including a list of questions related to two main themes derived from the research questions: 1. Entrepreneurial activities of Cameroonian migrants in Germany and 2. Contribution to the economic development of their host country (Germany) and the country of origin.

Due to the difficulty to convince Cameroon migrant entrepreneurs to record any conversation, the interviews were not recorded, they were only based on the interview guide with a list of questions.

The researcher had a guideline and at the same time, he explained every question and/or he made follow-up questions from the previous questions. The interviewer followed the guide, but he was able to follow other topics related in the conversation, when he considered appropriate. This method has the objective to understand better the entrepreneurial activities of the the immigrant entrepreneurs interviewed.

\section{$\underline{\text { Methodologies for analysis and discus- }}$ $\underline{\text { sion }}$}

The aspects described in the theoretical framework (summary presented in Table 1) will be the general themes to analyze for the case studies (from Vershiyi, 2014) selected for this research. This means that it is expected that the impacts of immigrant entrepreneurship for development are likely to be within the following areas (based on the scientific studies analyzed for the present paper):

Assessment of impacts in home countries:

1. Promotion of trade and FDI.

2. Skills and knowledge transfer.

Assessment of impacts in host countries:

1. Reduction of transaction costs of integration.

2. Skills and knowledge transfers.

3 . Reduction of poverty.

4. Increases in capital and market knowledge.

In order to carry out the present study, these areas will be used as a general framework to analyze the case studies presented.

\section{Case Studies and Analysis}

In this part, the case studies of two Cameroonian entrepreneurs in Berlin are presented. The interviews carried out were divided in two parts: The first part is a brief description of the company and the second part aims to understand better the entrepreneurial activities and characteristics, as well as the challenges they face when doing business in Berlin, Germany. Due to confidentiality reasons, the names of the companies are fictive names.

\section{Case Study 1 - Sawa Enterprise}

\section{Part 1: Brief description of the company}

This company is a registered enterprise acting as a holding for a group of companies in Berlin and it is located in the catchment areas of Berlin-Wedding. The firm is being owned and managed by a Cameroonian entrepreneur who is also the founder of the company. The enterprise has 3 employees who are employed on full time basis and has up to 5 part time work- 
ers on a free-lancer basis (upon demand). Sawa operates in the transport logistic sector. The main economic activities of this company are the export of cars to different countries in Africa and also food imports, mainly from Cameroon. Sawa Enterprise also operates a courier services but in partnership with a French postal services office, which is an agent for them.

Part 2: Information about the entrepreneurial activities and characteristics, the challenges they face when doing business in Berlin, Germany

The courier services developed as a result that the owner realized that once the customers were shipping cars to Africa, there was the need to post the bill of loading and car documents, which was only possible after the car had departed, and these documents had to get to destination before the shipment arrive its destination land.

Besides the courier services, the company has also other transportation services. Every month it exports at least 5-10 to 40 feet containers to Cameroon worth of goods which are mainly from scale exporters and private individuals.

This company has existed for over 10 years and operates in a "one phone call" away for logistic solutions. Whatever one wants to send to Cameroon in terms of goods, they are a phone call away, they pick it up from wherever location in Germany at a fee and ship for the customer. The customer is being billed with clearance duties in Cameroon inclusive. A simple example: if one has a bag or suitcase or a single piece item of up to $75 \mathrm{~kg}$., it will cost 100 Euros to get it transported and cleared in Douala and the contact person picks it up from the company's warehouse in Douala. As for cars, they are not responsible for port clearance, the customer has to manage it.

\section{Case Study 2 - Bami Enterprise}

\section{Part 1: Brief description of the company}

This company operates in a niche market and has been in operation for over 8 years. The company is an African food shop that sells African food stuff with predominant food stuff from Cameroon.
Part 2: Information about the entrepreneurial activities and characteristics, the challenges they face when doing business in Berlin, Germany

It is a private owned shop and it operates mostly as a family shop with family members working there. It has no registered employees because it is strictly a family business. Much description cannot be given to its activities because it is just a shop like any conventional shop that sells food items with the particularity that these food items one can find here are exclusively African. It also sells cosmetics and some perishables.

Unfortunately, the proprietor did not want to discuss more about where and how he obtains his merchandise from Cameroon for fearing of transferring the information to the researcher, who could become a potential competitor.

This case also exposes the difficulties and clichés for foreigners doing business in Germany and hold especially for Cameroonians. For example, from the telephone interview conducted with this entrepreneur, he mentioned one of the strategies for success and survival for a foreigner operating a business in Berlin: "move on the fast lane but don't stay on the fast lane because it catches up with you". This expression could be interpreted as staying smart and being on top of the game break the rules at time but don't break it for too long because if you do, you will definitely get into trouble.

A common aspect to highlight for both cases is also the relevance of remittances to the home country. This money is transferred by migrants abroad to their families and relatives and love ones back to their homeland to support in whatever way. The entrepreneurs indicated that they regularly send money back home to Cameroon.

\section{Analysis of the Case studies presented}

Based on the data collected of the case studies presented before, the following Tables 2 and 3 summarize key observations in the categories related with the impacts in the home country and host country of the entrepreneurs according to the scientific literature summarized in Table 1 above. This method was the basis for the analysis of the data for the purposes of this explorative paper. 
Table 2. Findings Case Study 1: Sawa Enterprise

\begin{tabular}{|c|c|c|c|}
\hline $\begin{array}{c}\text { General description } \\
\text { of Case Study } 1 \\
\text { and Observations }\end{array}$ & Impacts & $\begin{array}{c}\text { Impacts } \\
\text { in home country }\end{array}$ & $\begin{array}{c}\text { Impacts } \\
\text { in host country }\end{array}$ \\
\hline \multirow{8}{*}{$\begin{array}{l}\text { Case Study 1: } \\
\text { Sawa enterprise } \\
\text { General description: } \\
\text { Transport logistic } \\
\text { sector (export } \\
\text { and imports); } \\
\text { courier services } \\
\text { in partnership with } \\
\text { a French postal } \\
\text { services office. }\end{array}$} & Promotion of trade & Yes & Yes \\
\hline & Promotion of FDI & No direct evidence & No direct evidence \\
\hline & $\begin{array}{l}\text { Skills knowledge } \\
\text { transfers }\end{array}$ & $\begin{array}{l}\text { No direct evidence, } \\
\text { just evidence from } \\
\text { contacts abroad }\end{array}$ & No direct evidence \\
\hline & Remittances & Yes & Yes \\
\hline & Reduction of poverty & Yes & Yes \\
\hline & $\begin{array}{l}\text { Increases in capital } \\
\text { and investments }\end{array}$ & Yes & Yes \\
\hline & $\begin{array}{l}\text { Increases in market } \\
\text { knowledge }\end{array}$ & Yes & Yes \\
\hline & $\begin{array}{l}\text { Reduction } \\
\text { of transaction costs } \\
\text { of integration }\end{array}$ & Yes & Yes \\
\hline
\end{tabular}

Source: own elaboration from the author, based on observations from the Case studies in Vershiyi (2014).

Table 3. Findings Case 2: Bami Enterprise

\begin{tabular}{|c|c|c|c|}
\hline $\begin{array}{c}\text { General description } \\
\text { of Case Study } 1 \\
\text { and Observations }\end{array}$ & Impacts & $\begin{array}{c}\text { Impacts } \\
\text { in home country }\end{array}$ & $\begin{array}{c}\text { Impacts } \\
\text { in host country }\end{array}$ \\
\hline \multirow{8}{*}{$\begin{array}{l}\text { Case Study 2: } \\
\text { Bami enterprise } \\
\text { General description: } \\
\text { African food shop, } \\
\text { with predominant } \\
\text { food from Cameroon }\end{array}$} & Promotion of trade & Yes & Yes \\
\hline & Promotion of FDI & No direct evidence & No direct evidence \\
\hline & $\begin{array}{l}\text { Skills knowledge } \\
\text { transfers }\end{array}$ & No direct evidence & No direct evidence \\
\hline & Remittances & Yes & Yes \\
\hline & Reduction of poverty & Yes & Yes \\
\hline & $\begin{array}{l}\text { Increases in capital } \\
\text { and investments }\end{array}$ & Yes & Yes \\
\hline & $\begin{array}{l}\text { Increases in market } \\
\text { knowledge }\end{array}$ & Yes & Yes \\
\hline & $\begin{array}{l}\text { Reduction of } \\
\text { transaction costs of } \\
\text { integration }\end{array}$ & Yes & Yes \\
\hline
\end{tabular}

Source: Own elaboration from the author, based observations from the Case studies in Vershiyi, 2014.

\section{Discussion and Conclusions}

\section{Promotion of trade and Foreign Direct Investment (FDI)}

For both case studies presented in this paper, it is clear that they directly promote trade in their home and host country with their business activities described. Cameroonians entrepreneurs make use of any single opportunity that comes up to do business back at home in any form by building on their business experiences (Vershiyi, 2014). 
The relationship between trade and business diasporas to facilitate international commerce have been explored in the scientific literature (Cohen, 1997). Immigrants linkages to their home countries can play a relevant role in order to promote bilateral trade linkages. These connections include knowledge of home country markets, languages, preferences and business contacts with the potential to facilitate and decrease the trading transaction costs (Gould, 1994). Diaspora members create connections between producers and consumers in both host and home countries. Theses linkages promote the internationalization of products and services in the countries involved in form of exports and imports, as well as FDI (Foreign Direct Investment). Nevertheless, the two cases analyzed here do not show a direct evidence of promotion of foreign direct investment.

\section{Skills and knowledge transfer}

Skills and knowledge transfer represent a key impact for every society. But, for both cases presented in this paper, there is not direct evidence of skills and knowledge transfer. It is clear that for the entrepreneur of case study 1 (Sawa Enterprise), the contacts abroad (in Germany and in France) are relevant to transfer this valuable networking for trading purposes in his home country, but also for the host country, since the customer in the host country gets also the advantage of a "native" trade promotor, who has specific market knowledge of his home country and this facilitates the international trading. According to Newland and Plaza (2013), valuable skills, experiences and contacts abroad are part of the contributions that immigrants can transfer to their home countries. Nevertheless, here have been analyzed only two exploratory case studies from Cameroonian entrepreneurs in Germany. Therefore, it is necessary to develop further cases with immigrant entrepreneurs from different countries, as well as using qualitative and quantitative methods to explore and analyze closely this phenomenon.

\section{Reduction of transaction costs of integration}

Both cases show that the entrepreneurial activities of the Cameroonian diaspora reduce the transaction costs of integration, since it is normally difficult for foreigners to integrate into the labour market in Germany. To become an entrepreneur is usually a good possibility for many foreigners to integrate into the German labour market. This phenomen is congruent with one of the approaches discussed in the area of immigrant entrepreneurship: the structuralist approach. This approach states that external factors such as discrimination or entry barriers in the labor market due to education and language insufficiency, forces immigrants into self-employment. The 'disadvantage theory' is part of the structuralist theories, derived from the sociology and it attempts to explain ethnic entrepreneurship in the light of the difficulties encountered by immigrants in a host country (Vershiyi, 2014). But, the entrepreneurial activity of immigrants is particularly relevant for themselves and for Germany: because the integration of the "stranger" can proceed more quickly based on trust and recognition. Successful foreign entrepreneurs gain recognition also among the autochthonous population and their success causes an integrative effect (Dornberger et al., 2009). Both the social and economic benefits that could be achieved from economic empowerment of African business owners would translate to less people depending on state benefits, more taxes collection, freeing up public finances for other social benefits, etc. At the same time, successful immigrant entrepreneurs will be empowering their home country. In other words, supporting immigrant entrepreneurship is economically rewarding and socially beneficial (Vershiyi, 2014).

The case studies show that Cameroonians in Berlin do not fully belong to the German society; they are aspiring to eventually return to Cameroon in some years. The spirit of not belonging and fully integrated in the German society can be seen in their creation of associations to keep their patrimony intact and constantly fell at home away from home (Vershiyi, 2014).

\section{Reduction of poverty}

The promotion of entrepreneurship and private sector development are important pillars to reduce poverty in every society. The entrepreneurial activities presented in the case studies show the potential of the 
migration to reduce poverty in both the host and the home country, by promotion entrepreneurship in both sides. The ideas, resources and employment opportunities of transnational immigrant entrepreneurs can be able to impact not only in the economic, but also in the social development of their home countries (Kuznetsov, 2006 and Sørensen, 2006). Particularly the social impact of the ideas and resources from the host countries have frequently a positive influence in improvement of education and innovation in the home countries.

\section{Increases in capital and market knowledge}

In order to be able to develop an entrepreneurial activity in Germany, both Cameroonian entrepreneurs of the present studies needed to invest capital to start-up their ventures and to maintain their business in operation (one case over 10 years and the other over 8 years). At the same time, it was necessary that they know about the market where they are selling (Germany) and the market abroad related with their entrepreneurial activity (in these cases, Cameroon).

\section{Remittances}

Even though economic development goes beyond remittances (Newland and Plaza, 2013), migration and remittances is still a relevant co-insurance livelihood strategy by households and families in many parts of the world. This also applies for both cases analysed in this paper. This is part of the improving well-being, stimulate economic growth and to reduce poverty in different ways (de Haas, 2007).

\section{Limitations}

One of the most important limitations is that the entrepreneurial activities in the Cameroonian diaspora are at an early stage and mostly informal. Besides, considering the fact that the sample was obtained from networking contacts, this might have taken into consideration only the people who are regular to that area (in this case, BerlinWedding, where there is an important group of Cameroonians in Berlin). Those from other parts were not taken into consideration or those groups of people who do not visit these areas.
Implications for theory, practice and further research

This research contributes to the current discussion on immigrant entrepreneurship in Germany and shows the relevance of this kind of entrepreneurship not only in the host country, but also in the home country of the entrepreneurs as well. Both cases analyzed show the positive use of the entrepreneur's potentials and networks for the international linkage creation between different countries. As mentioned in the introduction, the promotion of such potentials is an important building block for the competitiveness in Germany and at the same time supports the economic development in other countries within an economic relation with Germany (Dornberger et al., 2009). This research also contributes to fill the gap in the existing scientific literature (explorative) on immigrant entrepreneurship with a focus on Cameroonian entrepreneurs in Germany.

Policy makers in Germany and in other countries should draw their attention to the potential and benefits of the immigrant entrepreneurship, formulating regulations that promote and strength international entrepreneurship, for instance, business support services and access to capital and loans in both countries involved. At the same time, the import/export procedures should be simplified and policy makers should take the advantage of the valuable immigrant knowledge for international trading and market knowledge.

\section{References}

Aliaga-Isla, R. and Rialp, A. (2013). Systematic review of immigrant entrepreneurship literature: previous findings and ways forward. Entrepreneurship and regional development, October.

Altinay, L. and Wang, C. (2009). Facilitating and maintaining research access into ethnic minority firms. Qualitative Market Research: An International Journal, 12(4), 367-390.

Baycan-Levent, T. and Nijkamp, P. (2009). Characteristics of migrant entrepreneurship in Europe. Entrepreneurship \& Regional Development, 21(4), 375-397.

Cohen, R. (2008). Global diasporas: An introduction. Routledge.

Cohen, R. (1997). Global diasporas: An introduction. University of Washington Press, Seattle, Washington. 
Dana, L.P. (ed.) (2007). Handbook of research on ethnic minority entrepreneurship: A coevolutionary view on resource management. Edward Elgar Publishing.

Dayton-Johnson, J., Pfeiffer, A., Schuettler, K. and Schwinn, J. (2009). Migration and Employment, Promoting Pro-Poor Growth: Employment. Paris: OECD.

De Haas, H. (2010). Migration and Development: A theoretical perspective. International Migration Review, 44(1), 227-264.

Dornberger, U., Alexander, S. and Sosa, A. (2009). Ausländische Unternehmer in Leipzig. Studie zur Situation von Selbständigen und Unternehmern mit Migrationshintergrund in Leipzig. Working paper supported by SMILE (Selbstmanagement Initiative Leipzig), Leipzig University and HHL Leipzig Graduate School of Management.

Elo, M. (2014). Diaspora networks in international business and transnational entrepreneurship - a literature review. Zentra working papers in transnational studies, No. 40, November.

Elo, M., Harima, A. and Freiling, J. (2015). To Try or Not to Try? A Story of Diaspora Entrepreneurship. The Future of Global Organizing (Progress in International Business Research, 10, 283-293.

Gould, D.M. (1994). Immigrant links to the home country: Empirical implications for US bilatera trade flows. Review of Economics and Statistics, 76, 302-316.

King, R. and Collyer, M. (2016). Chapter 10 „Migration and development framework and its link to integration" in Integration processes and policies in Europe. IMISCOE Research series.

Kuznetsov, Y. (2006). Diaspora networks and the international migration of skills: how countries can draw on their talent abroad? World Bank Institute, WBI Development Studies.

Jones, M., Coviello, N. and Tang, Y. (2011). International entrepreneurship research (1989-2009): a domain ontology and thematic analysis. Journal of Business Venturing, 26(6), 632-659.

Leicht, R. and Berwing, S. (2016). „Gründungspotenziale von Menschen mit ausländischen Wurzeln Entwicklungen, Erfolgsfaktoren, Hemmnisse" (Kurzfassung mit vorläufigen Ergebnissen). Mannheimer Institut für Mittelstandforschung.
Mundra, K. (2005). Immigration and international trade: A semiparametric empirical investigation. Journal of International Trade and Economic Development, 14(1), 65-91.

McDougall, P. and Oviatt, B. (2000). International entrepreneurship: the intersection of two research paths. Academy of Management Journal, 43(5), 902-906.

Nkongolo-Bakenda, J.M. and Chrysostome, E.V. (2013). Engaging diasporas as international entrepreneurs in developing countries: in search of determinants. Journal of International Entrepreneurship, 11(1), 30-64.

Riddle, L. and Brinkerhoff, J. (2011). Diaspora entrepreneurs as institutional change agents: The case of Thamel.com. International Business Review, 20(6), 670-680.

Riddle, L., Hrivnak, G.A. and Nielsen, T.M. (2010). Transnational diaspora entrepreneurship in emerging markets: Bridging institutional divides. Journal of International Management, 16(4), 398-411.

Robson, C. (2002). Real World Research: A Resource for Social Scientists and Practitioner-Researchers. Wiley.

Sharma, K., Kashyap, A., Montes, M. and Ladd, P. (2011). Realizing the development potential of diasporas. United Nations University Press.

Sørensen, B. (2014). The Migration-Development Nexus: Diaspora as development agents. Master Thesis, Denmark University.

Sørensen, N. (2014). New Diversities, 16(2).

Vershiyi, B. (2014). Cameroonian Diaspora Entrepreneurship in Germany: A case study on Cameroonian Entrepreneurship in Berlin. Master thesis for the attainment of the academic degree of 'Master of Business Administration in Small and Medium-Sized Enterprise Development', International SEPT Program, Leipzig University, Intake 2012-2014.

Tung, R.L. (2008). Brain circulation, diaspora, and international competitiveness. European Management Journal, 26(5), 298-304.

https://www.statistik-berlin-brandenburg.de/ produkte/Jahrbuch/jb2017/JB_201701_BE.pdf, p. 50 (accessed January $24^{\text {th }}, 2018$ ) 